\title{
A influência da música de Heitor Villa-Lobos no primeiro e terceiro movimentos da Primeira Sinfonia de Claudio Santoro
}

\author{
Rafael Fajiolli Oliveira \\ Universidade de São Paulo \\ rafael.fajiolli.oliveira@usp.br
}

Resumo: A Primeira Sinfonia para duas orquestras de cordas, composta no ano de 1940, é uma das obras inaugurais da primeira fase (1939-1948) de Claudio Santoro (1919-1989), momento muito relevante, não apenas para o compositor, mas também para se compreender a história do progressista Movimento Música Viva, encabeçado por Santoro e Hans Joachim Koellreutter (1915-2005). A análise da Primeira Sinfonia de Santoro é reveladora ao demonstrar que o contato entre eles gerou importantes consequências para a produção da música erudita moderna no Brasil. O primeiro e terceiro movimentos apresentam abordagens composicionais que aproximam esta obra da chamada "estética da sonoridade". Entre os compositores pioneiros dessa corrente podemos incluir Villa-Lobos que, na época em que a Primeira Sinfonia de Santoro foi escrita, era a principal figura da música brasileira. Este artigo identifica alguns procedimentos harmônicos e melódicos usados por Santoro no primeiro e terceiro movimentos de sua Primeira Sinfonia, apontando algumas possíveis relações intertextuais com a obra de Heitor Villa-Lobos.

Palavras-Chave: Claudio Santoro; Heitor Villa-Lobos; Teoria e Análise; Composição; Intertextualidade.

\section{The influence of Heitor Villa-Lobos's music on the first and third movements of Claudio Santoro's First Symphony}

\begin{abstract}
The First Symphony for Two String Orchestras, composed in 1940, is one of the inaugural works of Claudio Santoro's first period (1939-1948), a very relevant moment, not only for the composer, but also for understanding the history of the progressive Música Viva Movement, headed by Claudio Santoro and Hans Joachim Koellreutter. The analysis of Santoro's First Symphony is revealing for demonstrating that the contact between them generated important consequences for the production of Modern music in Brazil. The first and third movements present compositional approaches that bring this work close to the so-called "aesthetics of sonority". Among the founder composers in this trend we may include Villa-Lobos, who, at the time that Santoro's First Symphony was written, was already the main figure in Brazilian music. This article identifies some harmonic and melodic procedures used by Santoro in the first and third movements of his First Symphony, pointing out some possible intertextuality with Heitor Villa-Lobos's works.

Keywords: Claudio Santoro; Heitor Villa-Lobos; Theory and analysis; Composition; Intertextuality.
\end{abstract}

\section{Introdução}

Claudio Santoro (1919-1989) é apontado por diversos musicólogos brasileiros, entre eles José Maria Neves (2008) e Vasco Mariz (1990), como um dos compositores brasileiros mais importantes do século XX e a principal figura da composição brasileira depois de Heitor Villa-Lobos (1887-1959). Além de ter escrito 14 sinfonias, Claudio Santoro também é autor de um amplo número de obras escritas para variadas formações instrumentais que transitam por diversos estilos ao longo das diversas fases de sua produção. Certamente, a complexidade da sua linguagem, assim como uma inquietação estética que o levava a buscar constantemente novos paradigmas, são motivos a despertar 
interesse e, em consequência, estudos sobre suas obras. Dentre os diversos trabalhos com base analítica que abriram novas perspectivas para a compreensão da obra de Santoro destacamos os de Mendes (2009), Larsen (2010), Coelho de Souza (2012) e Santoro (2017).

Segundo Mendes, a produção composicional de Santoro pode ser dividida em seis momentos. Atentamos inicialmente para a primeira fase (1939-1946), na qual se encaixa a Primeira Sinfonia para duas orquestras de cordas, que é marcada pelo uso do atonalismo livre e do atonalismo sistêmico. Essa opção pelo experimental influenciou os principais compositores que faziam parte do movimento Música Viva, arquitetado por Hans Joachim Koellreutter (1915-2005) com o objetivo principal de renovar o cenário musical brasileiro.

O contato entre Santoro e Koellreutter acabou desencadeando importantes consequências para a produção brasileira de música erudita. A prática composicional adotada pelo grupo Música Viva, que aderiram à técnica dodecafônica por influência de Claudio Santoro, é um exemplo destas consequências. De acordo com as palavras do próprio Koellreutter, podemos evidenciar a importância de Santoro para a escolha da estética seguida pelo grupo quando ele menciona a Primeira Sinfonia para duas orquestras de cordas de Santoro como obra inaugural do dodecafonismo no Brasil:

[...] Lembro dos primeiros trabalhos que [Santoro] fez comigo: a Primeira Sinfonia para duas orquestras de cordas e da Sonata para Violino Solo, e outra para Violino e Piano. [...] sei que ele se afeiçoou à música dodecafônica, eu mesmo não fazia música dodecafônica naquela época. Claudio Santoro foi a força motriz que me levou a abraçar o dodecafonismo, o contrário como todo mundo pensa. (KOELLREUTTER, apud LÍVERO DE SOUZA, 2003, p. 28).

Essa fase é de grande importância tanto para o desenvolvimento técnico de Santoro, como também para o seu reconhecimento internacional enquanto compositor. Foi a partir deste momento que Santoro começou seus contatos com o musicólogo uruguaio Curt Lange, figura fundamental para o desenvolvimento e divulgação da música moderna escrita na América Latina.

Datam de 1940 a Sonata para Violino Solo e a $1^{a}$ Sonata para violino $e$ piano, que foram as primeiras obras de Claudio Santoro dadas a conhecer ao grande público. A crítica franziu a testa escandalizada. O mesmo público e os mesmos comentaristas que apuparam e depois aplaudiram VillaLobos, iniciavam um novo ciclo. Mas voltemos às Sonatas e, em especial, à escrita para violino solo. Este trabalho, elaborado livremente, mais ou menos dentro da técnica dos doze sons, granjeou ao compositor o apoio de 
Curt Lange, o ativíssimo diretor do Instituto Interamericano de Musicologia, que editou a Sonata no ano imediato. A $1^{a}$ Sonata para violino e piano situa, porém, o seu autor mais intimamente no seio do dodecafonismo (MARIZ, 1990, p. 259).

Na segunda fase (1946-1948), Santoro passou por um momento de transição, na qual sua linguagem composicional esteve em processo de reformulação, produzindo peças que navegam entre a música atonal e nacionalista. Nesse momento, Santoro tinha a expectativa de produzir obras com características vanguardistas e engajadas politicamente, procurando aproximar-se mais do grande público, a partir do conteúdo político presente nas obras desta fase. Uma obra que caracteriza bem esse momento é Impressões de uma Usina de Aço, em que o compositor lida com uma narrativa de crítica social em conjunto com o vanguardismo artístico.

A terceira fase de Santoro (1949-1960), é marcada por forte influência do nacionalismo. Essa posição ideológica deveu-se à militância de Santoro no PCB (Partido Comunista Brasileiro), procurando durante este período aplicar em sua música a doutrina soviética do Realismo Socialista, conforme as diretivas de Jdanov. De acordo com o compositor Jorge Antunes:

Eu via Claudio Santoro como o homem audacioso e revolucionário que, no passado, havia se alinhado às diretrizes do Congresso de Praga. Ele foi influenciado pelo zhdanovismo e pelo clima político da época de 1940. Eu sabia que Santoro, em 1946, havia deixado de usufruir de uma bolsa da Guggenheim Foundation por terem os norte-americanos lhe negado o visto de entrada nos EUA. A alegação era o simples fato de ser ele filiado ao PCB. [...] Jdanov exaltava o novo, defendia o melodismo, o epigonismo e condenava o ruído e o naturalismo. (ANTUNES, 2012, p. 105).

Essa fase também é caracterizada pela negação da estética serialista por parte de Santoro, como também pela negação dos experimentos e complexidades atonais advindas da música vanguardista do século XX. É neste momento que se dá o rompimento ideológico com Koellreutter. A seguinte citação do compositor argentino Juan Carlos Paz ilustra este momento:

Koellreutter, cultivando o terreno da prática e ao mesmo tempo o da prédica, obteve discípulos excelentes, alguns dos quais, lamentavelmente, abandonaram por razões políticas a causa do dodecafonismo: o que poderia indicar, à parte os ideais políticos divergentes, ter sido o dodecafonismo imposto e adotado muito superficialmente, ou ter a inoculação dodecafônica, com seu rigorismo de arte de formulação racional, se conservado estranha à exuberância e ao intenso lirismo apaixonado, e ao mesmo tempo primário, do temperamento local. (PAZ, 1976, p. 392). 
Em sua terceira fase (1949-1962), Santoro passa a compor obras menos complexas ou com algum engajamento político, como é o caso de Canto de Amor e Paz, da Elegia, das Danças brasileiras, entre outras. Essas obras foram escritas a partir de procedimentos composicionais mais tradicionais, procurando privilegiar os elementos nacionais. Nesse período, Claudio Santoro aproxima-se de compositores como Camargo Guarnieri e Guerra-Peixe.

A quarta fase de Santoro (1963-1989) é considerada por muitos autores como uma fase de maturidade do compositor. Isso manifesta-se na diversidade estética que o compositor apresenta na produção de obras a partir do uso de variadas técnicas e linguagens, demonstrando um domínio maior dos materiais. De acordo com Mendes:

Entendemos que uma pormenorizada reavaliação desta tão extensa e tão
pouco explorada etapa de produção (1960 - 1989), doravante subdividida,
tal como justificado acima, em três momentos claramente diferenciados,
"retorno ao serialismo" (1960-1965), "vanguarda" (1966-1977),
"maturidade" (1978-1989), juntamente com os mais tradicionalmente
abordados períodos iniciais, "dodecafônico" (1939-1946), "transição"
(1946-1948) e "nacionalista" (1949-1960), contribuiria sobremaneira em
prol de uma noção mais apropriada e abrangente deste conjunto de obras
tão marcado por sua diversidade. (MENDES, 2009, p.2).

Mendes subdivide o quarto período criativo de Santoro em três momentos. Entre os anos de 1960 até 1965, observamos um retorno ao serialismo dodecafônico, com obras como o $6^{\circ}$ Quarteto de Cordas, o $7^{\circ}$ Quarteto de Cordas e os Cinco Esboços para Orquestra, entre outras. Entre os anos de 1966 e 1977, vemos uma produção vanguardista muito rica, em que Santoro trabalhou com processos aleatórios e música eletroacústica. Este momento é marcado por peças como Diagramas Cíclicos, Aleatórios I, II e III, Mutationen I, entre outras. No terceiro momento, observamos obras que lidam com unidades sonoras mais familiares, retomando o sistema tonal de maneira mais madura. Peças como Fantasia, Concerto Grosso e Elegia I, são representativas deste momento.

\section{Influências no primeiro movimento "Allegro majestoso" da Primeira Sinfonia para duas orquestras de cordas de Claudio Santoro}

As sonoridades utilizadas por Claudio Santoro no primeiro movimento de sua Primeira Sinfonia, foram amplamente partilhadas por muitos compositores durante o século XX, principalmente por compositores que utilizaram escalas "exóticas" e estruturas simétricas com o objetivo de produzir certas sonoridades características. Tais 
autores foram associados a uma vertente da música pós-tonal em que a sonoridade era o principal fator estrutural das obras. Compositores como Claude Debussy, Maurice Ravel, Igor Stravinsky, Béla Bartók e o próprio Heitor Villa-Lobos são alguns dos nomes eminentes comumente mencionados nesta vertente.

O próprio Santoro revela as influências "modernas" que teve, antes de seu contato com a música serial e com Koellreutter:

\begin{abstract}
Iniciei minha carreira de compositor aos 18 anos, escrevendo, inicialmente, obras onde se fazia sentir a influência de nossa música folclórica. Estudava naquele tempo Estética, e naturalmente os princípios filosóficos burgueses me encaminhavam diretamente para uma concepção de arte formal. [....] Foi assim que abandonando as tendências folclóricas, escrevi sonatas, quartetos e peças para piano procurando nas escolas francesas contemporâneas apoio formal. Quando eu era garoto era fã de Bach; aos treze anos de idade tocava no violino as Partitas de Bach. Quando eu comecei a compor, a primeira influencia que eu sofri foi de Debussy e Ravel; marcaram meus quinze aos dezessete anos. (SANTORO, apud MARQUES DE OLIVEIRA, 2005, p. 51).
\end{abstract}

Evidencia-se assim que a escola francesa de composição foi a principal fonte de aprendizado para Claudio Santoro no início de sua carreira como compositor, o que, certamente, o aproxima de Heitor Villa-Lobos que era, então, o principal compositor brasileiro. Compositores como Claude Debussy e Maurice Ravel foram as principais referências de música contemporânea para o jovem Claudio Santoro, algo que é percebido tanto no primeiro movimento, como também no terceiro movimento de sua Primeira Sinfonia. No primeiro movimento podemos observar uma maior presença da escola francesa. Por outro lado, no terceiro movimento, observamos uma maior proximidade de autores como Stravinsky e Villa-Lobos, que engendram sonoridades mais densas em suas obras com caráter mais vanguardista.

As citações a seguir, revelam-nos outro autor, Paul Hindemith, que também foi fundamental para o desenvolvimento da linguagem composicional de Claudio Santoro:

Depois que eu conheci o Hindemith [...]; estudei pela escola de composição de Hindemith, aliás, escola que eu trabalhei com Koellreutter; eu tive também uma certa influência do Hindemith. (SANTORO, apud MARQUES DE OLIVEIRA, 2005, p. 51).

Com essa inquietude, própria dos 19 anos, que conheci Koellreutter e este apoiando-me, começou a dar lições diárias, numa atividade permanente, dando-me a conhecer os grandes mestres do formalismo, principalmente Hindemith que muito contribuiu para a minha formação técnica de compositor (Santoro, [195?]) (SANTORO, apud MENDES. 2009). 
Portanto, de acordo com o próprio Santoro, a música de Paul Hindemith foi importante para a sua formação. Santoro conheceu a técnica e pensamento composicional de Hindemith nos estudos com Koellreutter, diferentemente da música de compositores como Debussy e Ravel que já conhecia anos antes de começar seus estudos com Koellreutter.

A linguagem composicional desenvolvida por Hindemith, o aproxima de compositores que foram influenciados pelo jazz e incorporaram em suas estruturas harmônicas o uso de acordes quartais que se relacionam em grande medida com estruturas pentatônicas. No primeiro movimento da Primeira Sinfonia de Santoro, podemos encontrar, pontualmente, a utilização de sonoridades quartais, como ocorreu no primeiro tema harmônico com o uso do tricorde 3-9 (027) (ver Fig. 1).

A progressão harmônica contida nos compassos 2-3 e 16-17 apresenta a mesma sequência de acordes representada pelos conjuntos de classes de alturas 3-12, 4-26, 5-33 e 3-9. Como podemos constatar na Figura 1, o tricorde 3-12 (048), que representa a tríade aumentada, relaciona-se com o pentacorde 5-33 (02468), sendo ambos os acordes contidos na coleção de tons inteiros representada pelo hexacorde 6-35 (02468T). Portanto, podemos afirmar que os conjuntos 3-12 e 5-33 são subconjuntos da escala de tons inteiros. Outra característica importante é que a tríade aumentada 3-12 também é subconjunto do próprio pentacorde 5-33, designando uma escala de tons inteiros incompleta. Todavia, a tríade 3-12 tal como ocorre no fragmento em questão, formatada com as alturas de Sib, Solb e Réb, não está contida no agrupamento 5-33 que, no exemplo em questão, foi gerada a partir das alturas de Sol, Mib, Fá, Dó\# e Si. Ou seja, apesar de ambos os acordes serem subconjuntos da coleção de tons inteiros, entendemos que esses acordes correspondem a diferentes níveis de transposição desta coleção.

Quando esses acordes, em suas respectivas transposições, são somados, obtemos o octacorde representado pelo conjunto 8-19 (01245689), designando uma escala eneatônica 9-12 (01245689T) incompleta. Essa coleção foi nomeada pelo compositor francês Olivier Messiaen como seu Modo 3 de transposição limitada. Da mesma maneira, Messiaen nomeia a coleção de tons inteiros como Modo 1 de transposição limitada. Essas escalas (ou modos de transposição limitada) possuem características importantes, como o elevado grau de simetria e a facilidade de modulação entre si. Percebemos que a simples 
combinação de subconjuntos em diferentes níveis de transposição da escala de tons inteiros foi capaz de gerar uma versão incompleta do modo 3 de transposição limitada, aumentando o cromatismo a partir de estruturas com elevado nível de simetria.

Ainda examinando a estrutura harmônica encontrada nos compassos 2-3 e 16-17, observamos que os acordes representados pelos conjuntos 4-26 (0358) e 3-9 (027) não são subconjuntos da coleção de tons inteiros. No entanto, é possível identificar que o tetracorde 4-26 e a tríade 3-9 são complementares, gerando, quando somados, a coleção pentatônica paradigmática 5-35 (02479) (Fig. 1).

FIGURA 1

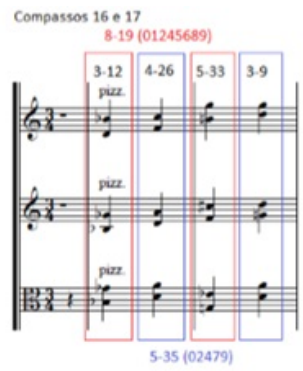

Comencoses 203

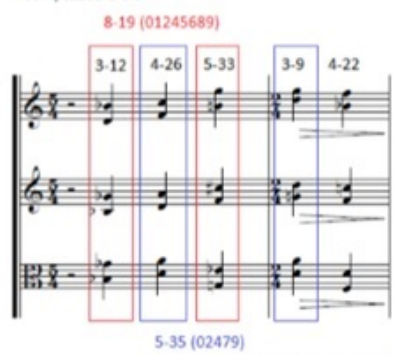

Compassos $20 \cdot 21$ 8.13 (01234679)

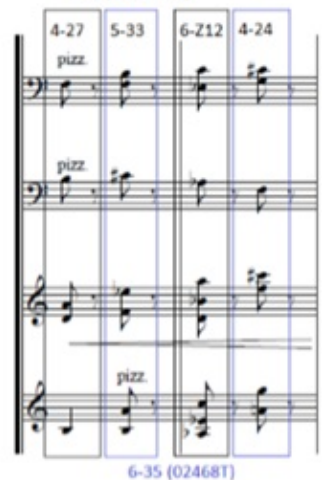

Primeiro tema do primeiro movimento "Allegro Majestoso" da Primeira Sinfonia de Santoro. Fonte: produção própria. 
Ainda podemos destacar algumas qualidades que conferem individualidade a essas sonoridades. A tríade aumentada 3-12 (048), além de ser subconjunto das coleções 6-35 e 9-12, é sonoridade fundamental para caracterizar a última coleção, isto é, o Modo 3 de transposição limitada. De acordo com as listas de Classes de Conjuntos de Allen Forte (1973) a tríade aumentada é complemento e unidade geradora deste nonacorde, uma vez que, três transposições desta tríade, relacionadas por semitons, acaba gerando tal coleção de nove elementos.

O tetracorde 4-26 (0358) representa uma sonoridade muito comum no sistema harmônico tonal, sendo um acorde menor com sétima ou, de acordo com o exemplo em questão, um acorde de Ré menor com sétima.

O pentacorde 5-33 (02468) é uma escala de tons inteiro incompleta que, neste exemplo, foi produzida pelas alturas de Si, Dó\#, Mib, Fá e Sol, isso é, a segunda transposição ou coleção impar desta escala, uma vez que, ao converter essas alturas em numerais, observamos a forma normal $[11,1,3,5,7]$, ou seja, todos os números de classes de altura, nessa transposição, são ímpares.

O conjunto 3-9 (027) designa um agrupamento triádico quartal, isso é, uma tríade gerada a partir de empilhamentos de quartas justas, como podemos ver na tríade em questão, que foi produzida pela sobreposição das alturas de Lá, Ré e Sol. Essa sonoridade caracteriza bastante a coleção pentatônica 5-35 (02479), pois ambos os agrupamentos são construídos a partir de processo semelhante, visto que, esta coleção pentatônica pode ser obtida através de sobreposição de quartas justas que, nos fragmentos estudados, pode ser gerada a partida da sequência de notas: Lá, Ré, Sol, Dó e Fá.

$\mathrm{Na}$ harmonia do tema dos compassos 2-3, podemos ainda identificar uma sonoridade adicional, produzida pelas alturas de Sib, Dó, Ré e Fá, sendo também representada pelo conjunto 4-22 (0247). Portanto, temos novamente uma sonoridade que faz referência a coleção pentatônica 5-35, sendo uma formação incompleta de tal coleção. No entanto, na primeira ocorrência desse pentacorde, que foi gerado a partir da união entre os conjuntos 4-26 e 3-9, obtemos a forma normal [5,7,9,0,10]. Na ocorrência incompleta, representada pelo tetracorde 4-22, que finaliza este tema, observamos a forma normal $[10,0,2,5]$. Ou seja, temos duas aparições da sonoridade pentatônica 5-35 em transposições diferentes. 
Nos compassos 20 e 21 vemos a terceira aparição deste tema harmônico que, como já visto anteriormente, aparece com variação na sequência de acordes. Apresentando desta vez, as sonoridades denominadas pelas coleções 4-27 (0258), 5-33 (02468), 6-Z12 (012467) e 4-24 (0248). Tendo apenas o pentacorde 5-33 como sonoridade comum as estruturas harmônicas contidas nos compassos 2-3 e 16-17 Há também uma relação de familiaridade entre os conjuntos de classes de altura 5-33 e 4-24, sendo ambos os acordes subconjunto da coleção de tons inteiros. Diferentemente do processo que ocorreu com os conjuntos 3-12 e 5-33 nos compassos 2, 3, 16 e 17, no caso dos acordes apresentados nos compassos 20 e 21, as coleções 5-33 e 4-24, representados respectivamente pelas formas normais $[9,11,1,3,5]$ e $[5,7,9,1]$, estão contidas na mesma transposição da escala de tons inteiros.

O tetracorde 4-27 (0258) representa outra sonoridade muito presente no sistema harmônico tonal, designando uma tétrade de meio diminuto, que na disposição exposta nos c. 20-21, com as alturas de Si, Ré, Fá e Lá, obtemos o acorde de Si meio diminuto (Bm7b5). Por outro lado, o hexacorde 6-Z12 (012467) é a sonoridade acordal mais estranha da estrutura harmônica apresentada nos c. 20-21, não correspondendo a nenhuma sonoridade previamente estabelecida, além de ser uma estrutura assimétrica. Tal sonoridade acaba representando um elemento de instabilidade na harmonia, fator este, que também é fundamental para o bom fluxo do movimento harmônico. Este acorde também deve suprir a necessidade de saturação cromática que parece ser tão cara ao autor.

Na Figura 2 mostramos um fragmento da análise de Dmitri Tymoczko dos compassos iniciais de L'Isle Joyeuse de Debussy. Nesta análise podemos observar a maneira como Debussy relaciona diferentes escalas na estrutura de sua obra. Inicialmente, nos primeiros seis compassos, vemos a utilização da escala de tons inteiros sendo utilizada de maneira consistente na harmonia deste trecho. Na melodia aparecem algumas alturas estranhas que tornam esta estrutura mais densa, mas há a predominância de sonoridades da escala de tons inteiros que será importante para a "articulação entre seções" (TYMOCZKO, 2007, p.255). Um procedimento equivalente existe na estrutura harmônica do primeiro movimento da Primeira Sinfonia de Santoro. 
FIGURA 2

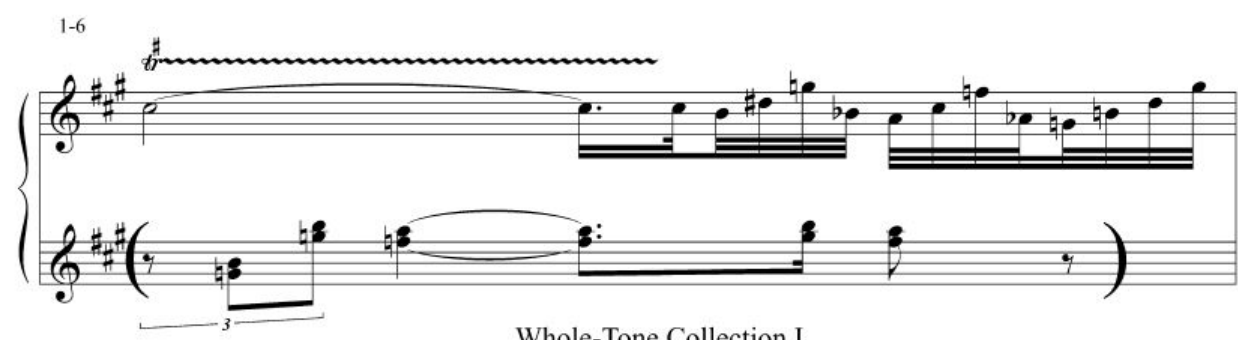

Whole-Tone Collection I

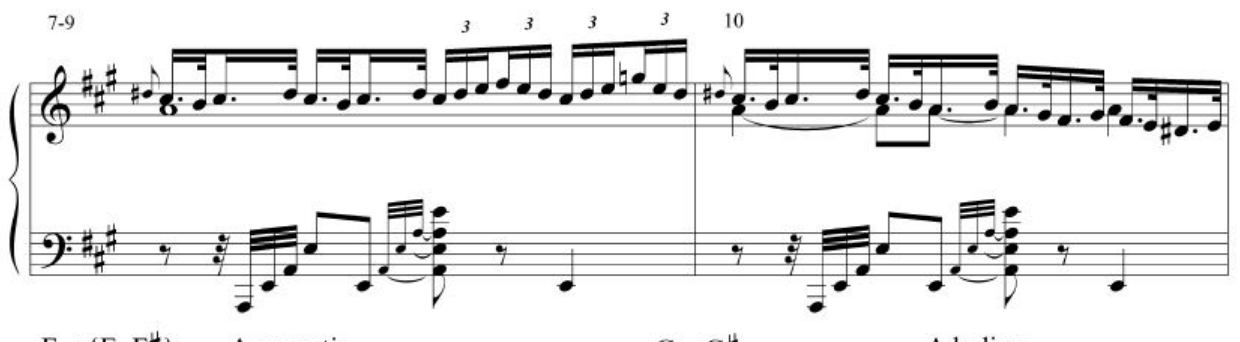

$$
\mathrm{F} \rightarrow\{\mathrm{E}, \mathrm{F} \sharp\} \quad \text { A acoustic } \quad \mathrm{G} \rightarrow \mathrm{G} \sharp \quad \text { A lydian }
$$

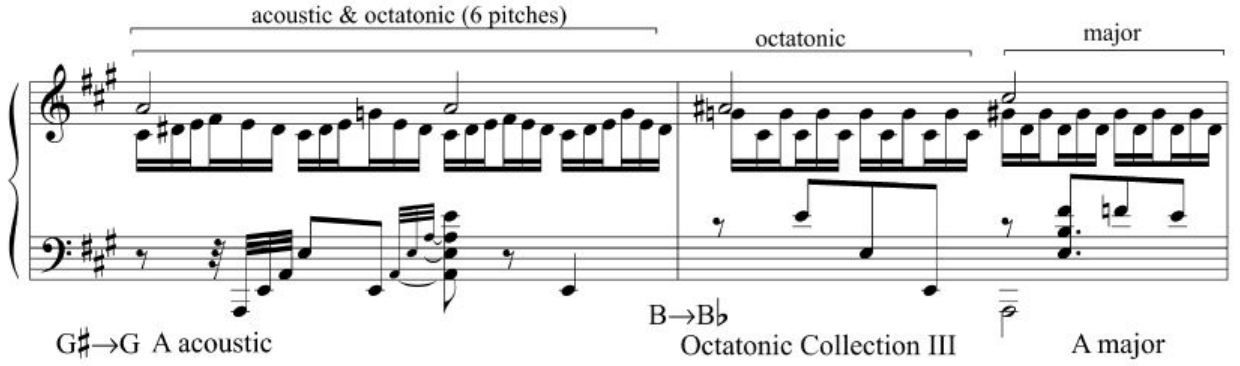

Análise de L'Isle Joyeuse de Debussy por Dmitri Tymoczko (TYMOCZKO, 2004, p. 256).

Nos compassos 7-9 da Figura 2, temos a utilização da escala acústica de Lá, gerada a partir da coleção de tons inteiros com acréscimo da nota Mi e alteração da nota Fá para Fá\#. No compasso 10 temos a escada diatônica de Lá lídio, que foi possível a partir da alteração de meio tom ascendente da nota Sol da escala acústica, que neste momento passa a ser Sol\# produzindo, com isso, a modulação entre essas coleções. No compasso 11 temos a volta para a escala de Lá acústica, com alteração retroativa da nota Sol\# que volta a ser Solł. Contudo, nesta segunda aparição da escala acústica, ela aparece incompleta, faltando a nota Si para a sua formação plena. No último compasso, observamos a presença da escala octatônica paradigmática em seu terceiro nível de transposição, que também ocorre em formatação incompleta, faltando a nota Dó. Tal coleção foi possível com o acréscimo da nota Sib à estrutura precedente, evidenciando mais uma modulação realizada a partir da escala acústica. No último compasso temos 
ainda uma modulação para a escala diatônica de Lá maior, com a volta das alturas Si e Sol\#.

Como podemos constatar a partir da análise de Tymoczko, a formatação da escala acústica favorece na possibilidade de efetuação de modulação entre diferentes coleções, possibilitando uma ampla gama sonora que pode ser alcançada de maneira sutil.

\begin{abstract}
A coleção acústica é muito próxima de duas outras coleções, compartilhando cinco das seis notas da escala de tons inteiros e seis das sete notas da escala diatônica. Desta forma. Debussy cria uma transição parcimoniosa tanto para as sonoridades familiares da escala diatônica, como também para as sonoridades exóticas da escala de tons inteiros. Esta foi uma das suas técnicas de composição mais favoritas, com progressões semelhantes aparecendo repetidamente ao longo de sua obra. (TYMOCZKO, 2011, p. 136).
\end{abstract}

A citação acima deixa claro a importância da coleção acústica para a música de Claude Debussy, tornando evidente a utilização desta escala como chave para alcançar sonoridades diferentes. Procurando unir diferentes mundos sonoros, uma vez que, a escala acústica é muito próxima tanto das coleções diatônicas utilizadas na música tonal e modal, como também das coleções simétricas como a escala de tons inteiros e a coleção octatônica. A seguir temos um trecho onde é exemplificado o uso da coleção acústica (734) na obra de Santoro.

\title{
FIGURA 3
}

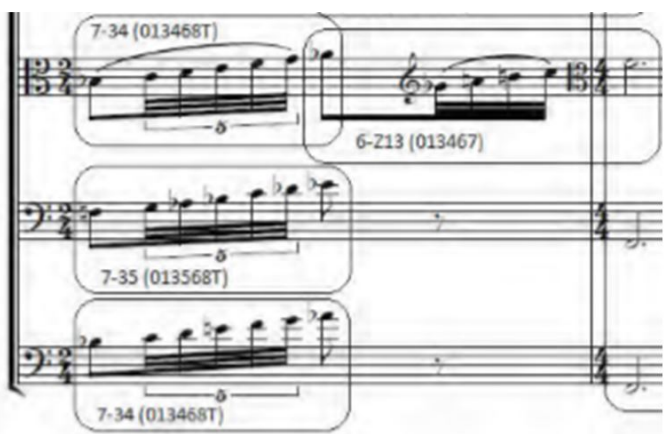

Santoro: Primeira Sinfonia, "Allegro majestoso", c. 129-130.

Como já afirmado, Debussy é uma das principais influências modernas em Claudio Santoro, antes mesmo de seu contato com Koellreutter. Isso já justificaria a presença de coleções como a de tons inteiros, a acústica e a pentatônica no primeiro movimento de sua Primeira Sinfonia. Apesar dessas coleções serem identificadas nessa peça, o procedimento de modulação não é identificado, pois Santoro trabalha com camadas e 
estruturas temáticas quase fixas, com poucas variações. Portanto a análise de Debussy é esclarecedora para se entender a linguagem de Villa-Lobos, mas não se aplica diretamente à Sinfonia de Santoro, que de fato usa sonoridades que encontramos em Villa-Lobos, as quais também remetem a Debussy, mas a sintaxe de Santoro ao empregá-las nesta sinfonia já é muito diferente da que reconheceu ter usado em sua primeira fase. Lembremos que Villa-Lobos também desenvolveu sua linguagem inicial a partir dos métodos franceses de composição. Joel Albuquerque observa a importância da escala acústica na obra de Villa-Lobos, que a utilizou de maneira semelhante a Debussy.

\begin{abstract}
Esta estrutura aparece muito frequentemente nas obras de Villa-Lobos até aqui analisadas, atuando principalmente como pivô no processo de transição entre pares. Essa função é desempenhada pelo conjunto 7-34 principalmente por sua característica híbrida, contendo implícito em si subconjuntos invariantes que formam simultaneamente segmentos quase completos de três coleções: diatônica, tons inteiros e octatônica (ALBUQUERQUE, 2014, p. 112).
\end{abstract}

Contudo, o procedimento que mais aproxima o primeiro movimento da Primeira Sinfonia de Santoro com alguns dos processos adotados por Villa-Lobos é a sobreposição de coleções pentatônicas "teclas pretas" com algumas formatações "teclas brancas" (tomando como referência as teclas do piano), isto é, a sobreposição de diferentes transposições da coleção 5-35 (02479), com a 7-35 (013568T). Segundo Jamary Oliveira:

O uso de Villa-Lobos nas possibilidades de alternância entre as teclas pretas e brancas, pode ser entendida de duas maneiras: primeiro, com a própria alternância e seu tratamento quanto ao número de notas, melódicas e harmônicas; E segundo, como formatação motívica e sua relação com a superação da subdivisão (OLIVEIRA, 1984, p. 35).

Apesar dos estudos de Jamary Oliveira terem como foco a música para piano de Villa-Lobos, sendo, portanto, a utilização das teclas pretas contra as teclas brancas um procedimento composicional que surge a partir de um impulso idiomático imposto pelo instrumento, assim como acontece com as transposições de formas de acordes que ocorrem com muita frequência na música escrita para violão deste autor. As sobreposições de diferentes transposições do pentacorde 5-35 transcendem a música para piano, ocorrendo também em obras camerísticas como os Choros $n^{\circ} 4$ e Choros $n^{\circ} 7$ (ALBUQUERQUE, 2014, p. 76).

Não é provável que o uso da escala pentatônica em Santoro tenha a mesma motivação de idiomatismo instrumental que em Villa-Lobos. Entretanto no primeiro movimento "Allegro Majestoso" da Primeira Sinfonia para duas orquestras de cordas, 
Santoro utiliza vastamente o pentacorde 5-35 na estrutura harmônica desta peça, ocorrendo em situações onde diferentes transposições a coleção pentatônica foram sobrepostas ou colocadas em sequência, assim como em sobreposição com outras coleções referências como a escala de tons inteiros. Entendemos que nesse sentido a influência de Villa-Lobos sobre Santoro possa ter ocorrido pelo conceito de sonorismo. Uma análise dos c. 103-112 do primeiro movimento da Primeira Sinfonia de Santoro (Fig. 4) ilustra essa afirmação:

FIGURA 4
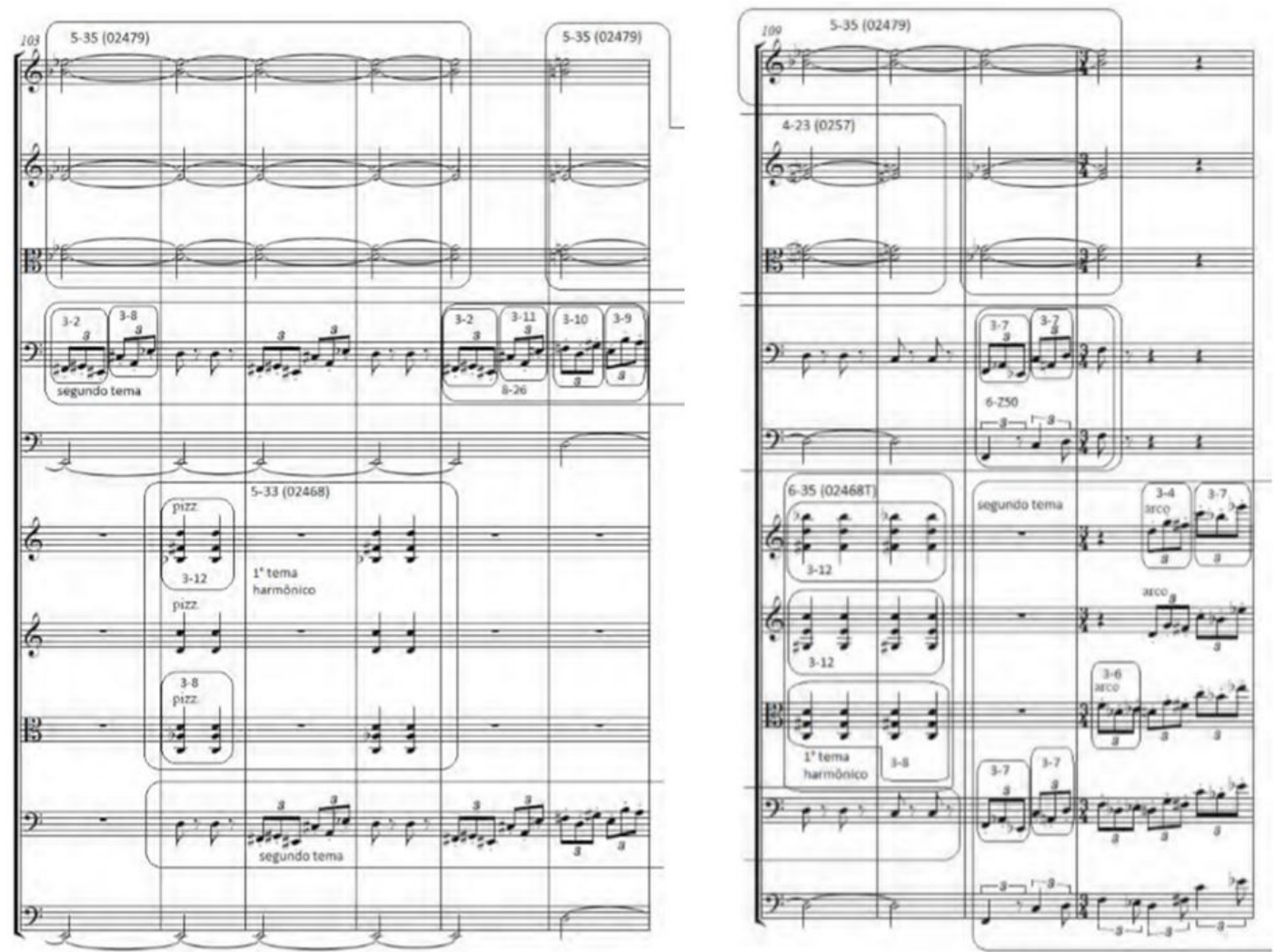

Santoro: Primeira Sinfonia, "Allegro majestoso, c. 103-112. Fonte: produção própria.

O que se constata na análise mostrada na Figura 4 é a utilização de sobreposições e justaposições do pentacorde 5-35 com outras coleções paradigmáticas. Nos compassos 103 a 107, a estrutura harmônica é mantida no primeiro e segundo violinos e viola da primeira orquestra. Esta estrutura harmônica foi gerada pelas alturas de Réb, Solb, Mib, Láb, Sib e Mib, isso é, a escala pentatônica 5-35 (02479) na transposição característica das teclas pretas do piano. 
No compasso 108, vemos a mesma formatação harmônica em transposição diferente, aparecendo com as alturas de Ré, Sol, Mi, Lá, Si e Mi, ou seja, uma transposição de meio tom acima da estrutura anterior, isto é, uma formação que usa só teclas brancas do piano. Logo, podemos dizer que entre os compassos 103-108, temos uma relação de transposição do pentacorde 5-35 que é análoga ao procedimento teclas pretas contra teclas brancas do piano, análoga ao uso frequentemente encontrado na obra de Villa-Lobos. A partir do compasso 109, outras formações quartais, em última instância decorrentes da pentatônica, são observadas.

No primeiro e segundo violinos e viola da segunda orquestra, observamos duas ocorrências do primeiro tema. A primeira aparição deste tema é nos compassos 104 a 106, com uma formatação harmônica associada ao pentacorde 5-33 (02468) com forma normal $[6,8,10,0,2]$, ou seja, uma coleção incompleta de tons inteiros em transposição par. Essa sonoridade foi gerada pela sobreposição dos tricordes 3-12 (048) no primeiro violino e 38 (026) na viola, tendo também o bicorde formado pelas notas Dó e Ré no segundo violino. Nos c. 103-107, nos contrabaixos de ambas as orquestras, temos a nota Mi sendo sustentada, completando a coleção de tons inteiros produzida pelo primeiro tema harmônico.

A sobreposição de um conjunto de $5 / 6$ da escala de tons inteiros com uma pentatônica, sem alturas compartilhadas, gera uma estrutura harmônica densa e complexa. É importante perceber que essas formatações ocorrem em timbres distintos. Enquanto a coleção pentatônica aparece nas cordas friccionadas por quatro compassos, o pentacorde de tons inteiros ocorre em pizzicato, produzindo, evidentemente, um efeito pontilhístico. Essa separação na orquestração permite haver uma percepção da sobreposição das duas formações harmônicas.

Nos c. 109-110, observamos novamente o primeiro tema harmônico sendo executado pelo primeiro e segundo violinos e viola da segunda orquestra. Neste momento temos a coleção de tons inteiros completa em transposição par, sendo representada pelo hexacorde 6-35 (02468T), tal escala foi obtida a partir de sobreposição entre duas tríades aumentadas 3-12 (048) no primeiro e segundo violinos e um tricorde 3-8 (026) na viola. Esta coleção aparece em sobreposição com aquela sonoridade que integra um bicorde formado pelas alturas de Sib e Mib no primeiro violino da primeira orquestra, com a 
tétrade 4-23 a escala pentatônica incompleta em transposição com alturas naturais no segundo violino e viola da primeira orquestra.

Na figura 4 também podemos ver a presença do segundo tema nos c. 103-111 nos violoncelos de ambas as orquestras, tendo continuidade a partir do c. $112 \mathrm{em}$ todos os instrumentos da segunda orquestra. Nos violoncelos das duas orquestras, a partir do c. 103, vemos um processo de fragmentação do segundo tema, que ocorre em grupos de seis e doze notas. Nos c. 103-108, observamos a presença de algumas sonoridades culturalmente características, tais entes sonoros foram representados pelos tricordes 3-2 (013), 3-8 (026), 3-9 (027), o tricorde quartal, 3-10 (036), o acorde diminuto 3-10 (036) e a tríade 3-11 (037) que corresponde ao acorde de Lá maior (Fig. 4). No c. 111, evidenciamos mais um fragmento do segundo tema que utiliza o hexacorde 6-Z50 (014679), uma escala octatônica incompleta, que, por sua vez, foi engendrada por duas tríades 3-7 (025), que é a unidade sonora mais presente na estrutura do segundo tema, como podemos visualizar nos c. 111-112 na segunda orquestra.

\section{Modos de transposição limitada no terceiro movimento "Allegro-final" da Primeira Sinfonia de Claudio Santoro}

Uma característica fundamental que é comum nas coleções simétricas utilizadas por Claudio Santoro nos primeiro e terceiro movimentos de sua Primeira Sinfonia, é que muitas dessas coleções estão entre os sete modos de transposição limitada, identificados pelo compositor francês Oliver Messiaen (1908-1992) no livro Technique de mon langage musical, publicado em 1942 (Fig. 5). Do ponto de vista das estruturas melódicas e harmônicas, a utilização de coleções simétricas engendradas a partir da divisão de oitavas em segmentos equivalentes é muito significativa para a linguagem de Messiaen. Obviamente Santoro não pode ter usado a teoria de Messiaen na composição da Primeira Sinfonia porque o livro só foi publicado posteriormente, mas é significativo que Santoro estivesse, na mesma época, empregando estruturações semelhantes às de Messiaen. 

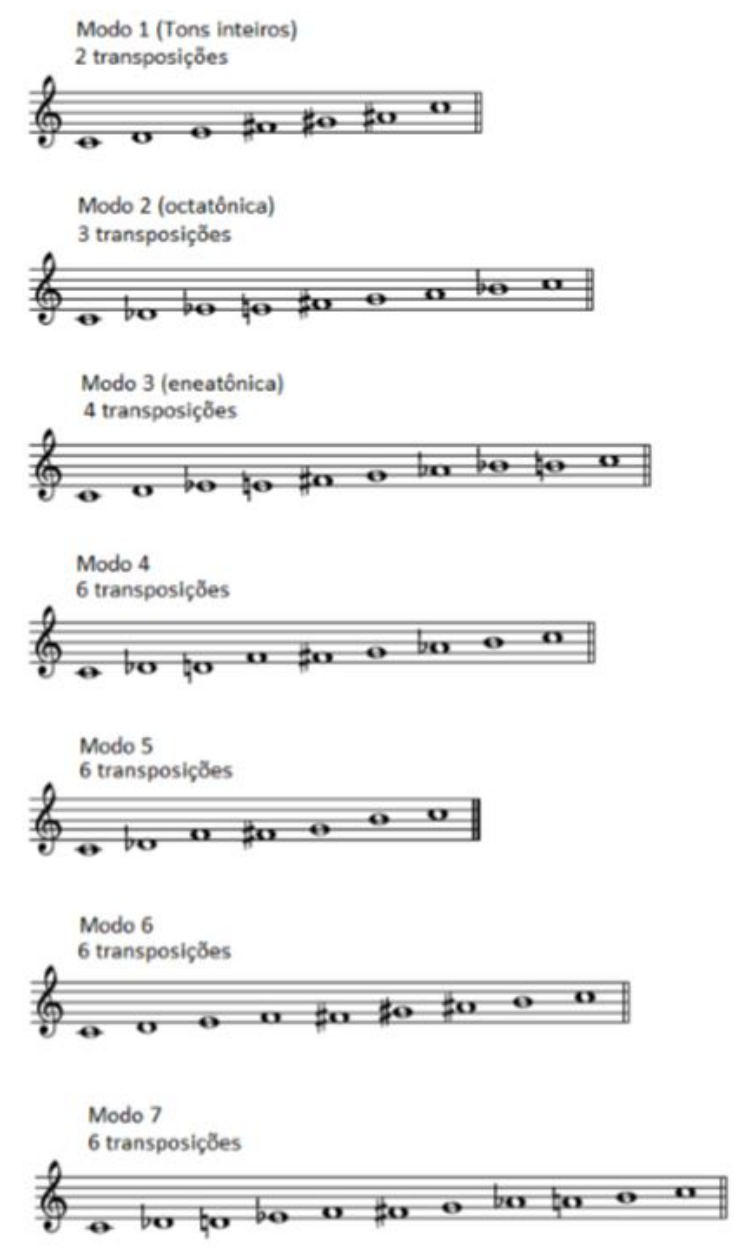

Os modos de transposição limitada, de acordo com Messiaen. Fonte: FRANCOLÍ, 2008 .

O modo 1 representa a coleção de tons inteiros, ou seja, o hexacorde 6-35 (02468T) que foi extensamente utilizado desde o século XIX e durante todo o século XX. Tal escala permite apenas duas possibilidades de transposição. O modo 2 é a escala octatônica paradigmática 8-23 (0134679T). Assim como o modo 1, já aparece na música escrita durante a segunda metade do século XIX e assume papel central durante grande parte do século XX. Esse octacorde permite apenas três transposições. O modo 3, a coleção eneatônica 9-12 (01245689T), de maneira menos frequente em relação aos modos 1 e 2, também tem ocorrência em músicas compostas durante a segunda metade do século XIX, sendo muito importante no engendramento de redes de acodes por relações parcimoniosas, e durante o século XX por compositores que consideravam as estruturas simétricas fundamentais para a sua linguagem, tal como, entre outros, o próprio Messiaen 
e Villa-Lobos. O nonacorde 9-12 (Modo 3 de transposição limitada) permite apenas quatro transposições.

Os modos 4, 5, 6 e 7 aparecem com menos frequência quando comparados com os modos descritos anteriormente. O modo 4 ou octacorde 8-9 (01236789) é gerado a partir de duas sequências de três semitons e um tom e meio ou por duas células $\mathrm{X}$ separadas por um tom e meio. O modo 5 representa o hexacorde 6-7 (012678) que pode ser entendido como um derivado do modo 4. O modo 6 também designa um octacorde que pode ser representado pelo conjunto de classe 8-25 (0124678T), sendo uma escala construída a partir de duas sequências intervalares formadas por dois semitons e dois tons. O modo 6 também pode ser obtido a partir do modo 7 a coleção 10-6 (012346789T), bastando eliminar o trítono gerado pelas alturas de Ré sustenido e Lá. Os modos 4, 5, 6 e 7 possuem seis possibilidades de transposição cada um. Apenas o modo 3 não é um subconjunto do modo 7. Essa característica é importante, pois a modulações entre os modos 1, 2, 4, 5, 6 e 7 acabam sendo realizadas por simples subtrações ou adições de trítonos. O trecho a seguir (Fig. 6) exemplifica como Claudio Santoro trabalhou alguns desses modos no terceiro movimento de sua Primeira Sinfonia.

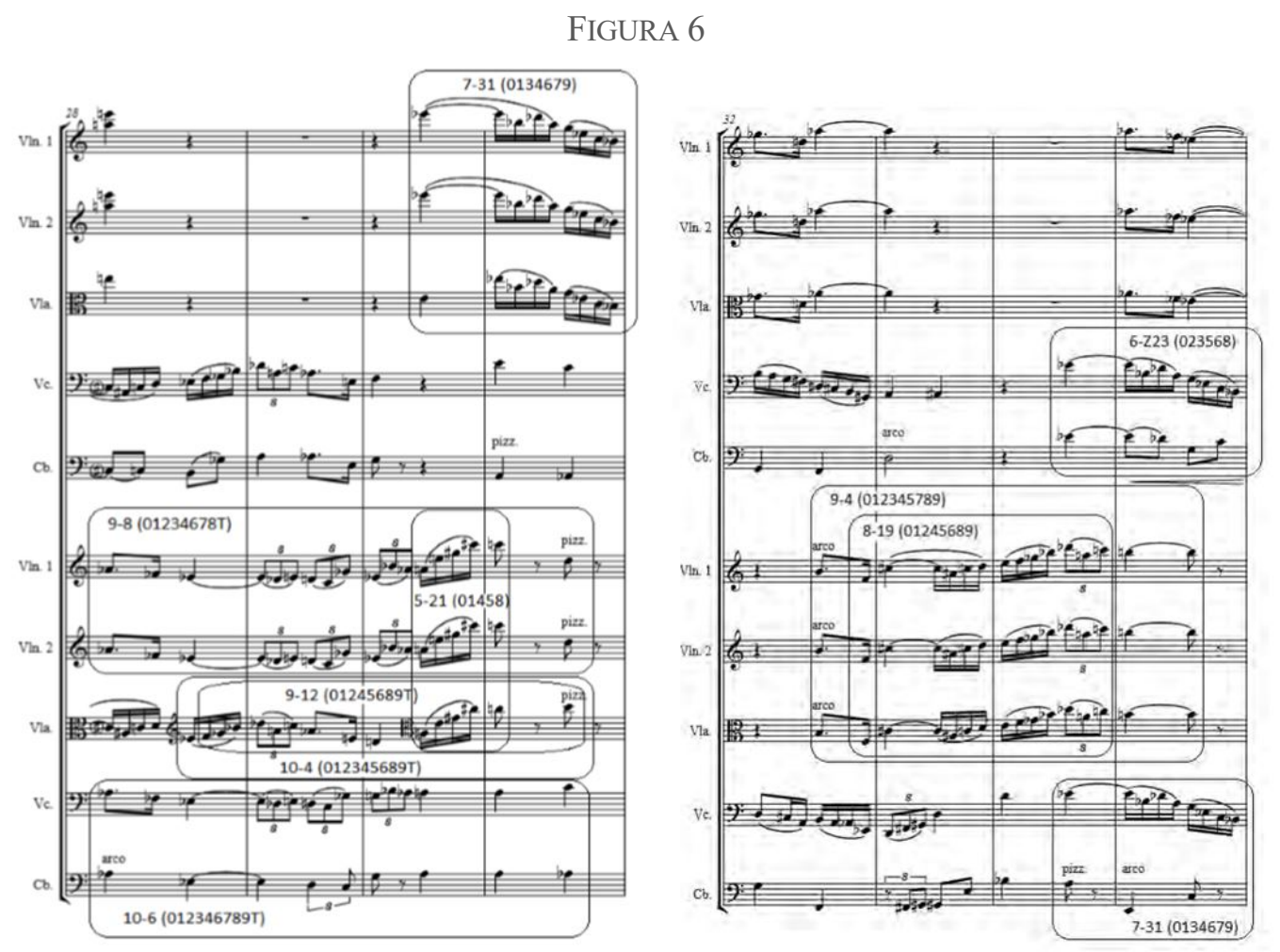

Santoro: Primeira Sinfonia, III, "Allegro - Final e Fugato", c. 28-35. 
Na figura 6 temos um pequeno trecho do terceiro movimento da Primeira Sinfonia de Santoro no qual podemos observar como foram utilizados alguns dos modos de transposição limitada. Entre os c. 28-31 temos, no primeiro e segundo violinos da segunda orquestra, um pequeno tema gerado pela coleção eneatônica 9-8 (01234678T) (modo 7 de transposição limitada), ou seja, o conjunto 10-6 incompleto. A forma normal desse tema é $[8,9,10,0,1,2,3,4,6]$, com as alturas Láb, Lá, Sib, Dó, Dó\#, Ré, Ré\#, Mi e Fá\#. A única altura que falta para completar o modo $7 \mathrm{em}$ sua primeira transposição ou formatação que coincide com sua própria forma prima é a nota Sol. No mesmo trecho, no violoncelo e contrabaixo da segunda orquestra, temos o modo 7 completo, no mesmo nível de transposição, como apontado na Figura 6. Observe-se que o violoncelo dobra o tema exposto pelo primeiro e segundo violinos (c. 28-29), enquanto o contrabaixo contrapõe esse tema com algumas alturas adicionais, dando ênfase às alturas de Lá e Láb. Nos c. 30-31 o violoncelo passa a contrapor o primeiro e segundo violinos introduzindo no c. 30 a nota Sol, que faltava para completar o modo 7.

Ainda observando os c. 28-31 (Fig. 6), vemos que o autor introduz, na viola da segunda orquestra, o modo 3 a coleção eneatônica 9-12 (01245689T) na sua plenitude e em transposição que coincide com sua forma prima. Observe que apesar do modo 3 ser o único modo de transposição limitada que não está contido no modo 7, ainda assim, esses modos são muito próximo em relação a subconjunto. $\mathrm{O}$ autor utiliza dessa proximidade entre esses modos para interligar algumas ideias que estão no âmbito das relações entre os motivos. Isso é evidente quando percebemos que ao final do c. 30 e início do 31 temos um motivo que é dobrado entre a viola e os violinos um e dois da segunda orquestra, enfatizando a sonoridade representada pelo pentacorde 5-21 (01458) que possui bastante recorrência durante o movimento estudado (Fig. 6).

A escolha da transposição a partir do Dó em ambos os modos acentua ainda mais a proximidade entre essas coleções, nesse sentido, no caso em questão, além de sobrepor diferentes modos também há relações contrapontísticas entre essas escalas favorecendo uma sonoridade específica, uma vez que, a única altura contida apenas no modo 3 é o Fá, como também, a única altura que não está presente em nenhum dos modos é a nota Si. Observe-se que o Fá na viola não teve muito destaque no exemplo em questão, apesar da evidente ocorrência com o possível propósito de diferenciar o modo 3 do modo 7. As alturas destacadas na linha da viola que ocorrem em tempo forte ou tem duração temporal 
superior são todas compartilhadas com o modo 7. Outra característica dessa linha da viola é a presença do Mib, altura estranha ao modo 3, que atua como um procedimento contrapontístico, iniciando o tema a partir do uníssono entre os violinos I e II da segunda orquestra. A altura seguinte ao Mib é justamente a nota Fá, um ponto de divergência entre os modos 3 e 7. Se considerarmos o Mib (na linha da viola) obtemos a coleção de dez elementos representada pelo conjunto de classe 10-4 (012345689T), que apesar de não ser um modo de transposição limitada de Messiaen, é também uma coleção simétrica (Fig. 6).

Nos c. 30-31, na viola e violinos I-II da primeira orquestra, temos a ocorrência do septacorde 7-31 (0134679), subconjunto da escala octatônica paradigmática (modo 2 de transposição limitada em sua primeira forma de transposição). A forma normal do septacorde 7-31 é [7,9,10,0,1,3,4], sendo formada pelas alturas de Sol, Lá, Sib, Dó, Réb, Mib e Mi. Com isso, podemos constatar que a altura que falta para completar o modo 2 é Solb. Nos c. 34-35 também há ocorrência do modo 2, exatamente no mesmo nível de transposição de sua aparição nos c. 30-31. Esse modo é tocado por violoncelos e contrabaixos de ambas as orquestras, gerando variação de tessitura e timbre, uma vez que, temos o mesmo material melódico e rítmico sendo trabalhado em ambas as situações.

Nos c. 32-34 temos mais uma ocorrência incompleta do modo 3 de transposição limitada, no tema dobrado por viola e violinos I e II da segunda orquestra. Tal modo pode ser representado pelo octacorde 8-19 (01245689), novamente, em transposição que coincide com sua forma primária. Assim é possível concluir que a altura excluída do modo 3 no exemplo em questão foi o Láb. Algo importante de ser percebido nessa passagem é a presença da nota Si nos c. 32 e 35 iniciando e finalizando o tema exposto pela viola e violinos da segunda orquestra. No término desse tema, a nota Si ocupa quase todo o compasso 35 .

Esse procedimento é interessante, pois os modos de transposição limitada 2, 3 e 7, que aparecem na passagem (Fig. 6), estão todos no mesmo nível de transposição, isso é, estão em formato escalar partindo da nota Dó. Quando essas coleções são contrapostas e somadas, é possível obter onze das doze alturas possíveis da escala cromática, faltando apenas a nota Si. É significativo o destaque da nota Si nesse momento, pois desestabiliza a sonoridade resultante dos três modos presentes na passagem, além de saturar 
cromaticamente os temas trabalhados. A nota Si aparece outras vezes no exemplo da figura 6 , por exemplo no contrabaixo da primeira orquestra no c. 28 ; no entanto essas aparições não estão em momentos de grande destaque, nem em estruturas recorrentes ou em temas acentuados a partir de dobramentos entre os instrumentos das orquestras. Apenas nos c. 32 e 35 há maior destaque da nota $\mathrm{Si}$, o que reforça a hipótese da instabilidade na estrutura sonora. Paulo de Tarso Salles (2009) aponta alguns procedimentos aplicados por Villa-Lobos para gerar instabilidade:

\begin{abstract}
A criação de entidades harmônicas simétricas - da forma como as empregou Villa-Lobos - em estruturas melódicas, ostinati, progressões de acordes ou em frases de prolongamento muitas vezes tem por finalidade a reiteração de elementos intervalares que conferem unidade harmônica, um ponto de partida estável, a partir do qual são combinados alguns outros elementos díspares. Assim, uma vez definido um "sistema" estável de sons, o compositor passa a sistematicamente decompor essa estabilidade, ora acrescentando outras estruturas superpostas, ora recortando elementos que desestabilizam e estabelecem movimento, dinamismo e tensão (SALLES, 2009, p. 52).
\end{abstract}

Na citação acima, Salles afirma que a constante quebra da estabilidade imposta por um sistema deve conferir movimento à obra. No caso de Villa-Lobos esse sistema é instaurado a partir da manipulação de entidades harmônicas simétricas que são quebradas em algumas ocasiões pontuais com o propósito de gerar instabilidade e, portanto, movimento a partir de tensão. Da mesma maneira, Claudio Santoro desenvolveu em sua Primeira Sinfonia um sistema sonoro baseado em coleções simétricas paradigmáticas, organizadas a partir de linhas melódicas sobrepostas em uma textura polifônica bastante densa. Ao destacar a nota Si, única altura não contida nas coleções da figura 6, Santoro gera instabilidade estrutural e consequentemente sonora. Tal instabilidade também pode ser constatada na coleção 9-4 (012345789) que é assimétrica e engendrada a partir do acréscimo da nota Si no tema em questão. Isso ocorre porque os outros temas (na Fig. 6) são coleções altamente simétricas; mesmo na primeira aparição do modo 3 nos c. 28-31 - onde há a ocorrência da "nota estranha" Mib, a coleção resultante foi o conjunto 10-4 (012345689T) que é simétrico, apesar de não ser um dos modos de transposição limitada. Na segunda ocorrência (incompleta) do modo 3 (c. 32-35), a "nota estranha” Si está em destaque, gerando a coleção assimétrica 9-4 e um momento de instabilidade. 


\title{
Possível influência de Heitor Villa-Lobos no terceiro movimento da Primeira Sinfonia de Claudio Santoro
}

Claudio Santoro, durante a primeira etapa de sua carreira, desenvolveu sua linguagem a partir, principalmente, da técnica dodecafônica, além de ter sido um crítico, em conjunto com seus companheiros de Música Viva, da música nacionalista. Barros (2010) comenta a perspectiva de Santoro e de seus companheiros do Movimento Música Viva em relação a música dita "nacionalista".

\begin{abstract}
É interessante lembrar, no entanto, que mesmo antes da ruptura com Koellreutter, Guerra Peixe e Santoro já teorizavam em termos muito próximos do que viria a ser sua forma de nacionalismo, escrevendo artigos para o Boletim Música Viva afirmando a importância do desenvolvimento de uma escola de composição brasileira com base no conhecimento das "características técnicas do folclore" que, em conjunto com o conhecimento da música contemporânea, "possibilitaria o surgimento de um sistema de composição legitimamente brasileiro." (Egg, 2004, p. 44). Além disso, quando o Santoro ainda dodecafonista dizia não ser contra o nacionalismo musical, definia no entanto o que se havia feito até então em termos de música nacional como "um tema ou dois já tão explorados (...) no meio, em geral, de uma balbúrdia de sons, sem uma determinada lógica para cuja finalidade devíamos senti-la", dando com isto o suposto "paladar nacional" (BARROS, 2010, p. 8).
\end{abstract}

Esse texto evidencia certa hostilidade entre os jovens compositores do movimento Música Viva em relação às obras nacionalistas criadas até então. Essas discussões foram motivadas por divergências de pensamento em relação a técnica composicional e ao entendimento de música nativa. Koellreutter entendia que toda música feita em território brasileiro deveria ser considerada como nativa, como também acreditava ser necessário uma renovação da técnica composicional. Por outro lado, Guarnieri, alinhado com as ideias difundidas por Mário de Andrade, acreditava que a técnica composicional deveria favorecer o engendramento de uma legítima música nacional erudita, relacionando materiais do folclore nacional e expressividade.

Villa-Lobos recebeu o rótulo de "nacionalista", talvez por conta de seus envolvimentos no movimento modernista brasileiro e posteriormente com o governo de Getúlio Vargas. No entanto, Villa-Lobos desenvolveu uma linguagem musical muito própria que se alinhava com compositores modernistas de seu tempo, como Bartók, Stravinsky, Debussy, Varèse, entre outros da primeira metade do século XX. Assim como seus contemporâneos, Villa-Lobos não inventou uma escola de composição brasileira, não fez discípulos, como também, sua música apesar da evidente influência Franco-Russa 
e da utilização de material folclórico não corresponde a nenhuma escola específica de composição, nem mesmo com as propostas de Mário de Andrade no Ensaio Sobre a Música Brasileira. Andrade, apesar de identificar certa nacionalidade na obra de VillaLobos, critica sua liberdade estética:

\begin{abstract}
Em Villa-Lobos a maneira de polifonisar já não é mais o emprego direto do processo popular mas uma ilação vasta dele. Si por vezes neste compositor o processo se conserva nacionalmente reconhecível (Seresta ${ }^{\circ}$ 11, "Redondilha" seresta $\mathrm{n}^{\mathrm{o}} 6$ "Na Paz do Outono" ed. C. Artur Napoleão), si por vezes a genialidade da invenção torna a obra impossível da gente discutir (o baixo obstinado de "Nesta Rua", Ciranda $\mathrm{n}^{\circ}$ 11) sempre isso contêm o perigo iminente de amolecer, abafar, desvirtuar o caráter nacional da invenção. E é mesmo o que sucedeu algumas feitas.

[...] Mas como a tudo quanto faz, Villa-Lobos imprimiu aos Choros, Serestas, Cirandas, uma feição individualista excessiva, não se utilizando propriamente das formas populares nem as desenvolvendo. (ANDRADE, 1972 [1928], p. 23; 29).
\end{abstract}

Se Mario de Andrade via a "espontaneidade" de Villa-Lobos como um problema para a realização de uma música nacional, Santoro interpretava esse aspecto da personalidade de Villa-Lobos como um elemento positivo. Entretanto, considerava isso insuficiente para a formação de uma escola de composição nacionalista. André Egg elabora essa ideia:

Para ele [Claudio Santoro], faltam a estes compositores imaginação criadora, conhecimento mais profundo da arte do país e uma lógica estruturante. Mais adiante, afirma que não considera toda a produção nacionalista perdida, destacando que "algo de espontâneo se encontra em certas composições de Villa-Lobos”, mas que isto não é suficiente para se considerar atingida a criação de uma "escola nacional" de composição. (EGG, 2005, p. 64).

Podemos afirmar que os compositores "nacionalistas" da época, de acordo com a estética de Mário de Andrade, eram Camargo Guarnieri e Francisco Mignone. VillaLobos manteve-se fora dessas discussões estéticas, sem demonstrar intimidação em relação as críticas de Mário de Andrade e alguns de seus contemporâneos. Por ocasião das discussões em torno da "Carta aberta aos músicos e críticos do Brasil”, onde Guarnieri expõe sua defesa irrestrita da música nacionalista, Villa-Lobos não demonstrou interesse em relação ao tema, não se manifestando em nenhum momento sobre o assunto. André Egg esclarece:

Em ocasiões posteriores em que se manifestou na imprensa Camargo Guarnieri demonstrou um certo ressentimento pelas reações que a Carta aberta suscitou. Apesar de receber inúmeros apoios, não conseguiu que se manifestassem publicamente aquelas figuras-chave do nacionalismo musical brasileiro, nomes que com seu prestígio poderiam somar muito à 
causa que Guarnieri pretendera levantar - principalmente os compositores Villa-Lobos, Francisco Mignone, Guerra Peixe e Claudio Santoro. Mignone e Santoro manifestaram apoio apenas por carta, mas não publicamente. Outra ausência sentida pelo compositor foi a do crítico Caldeira Filho, do Estado de São Paulo, que preferiu não participar da polêmica, que julgava inoportuna. (EGG, 2006, p. 6).

A Primeira Sinfonia de Claudio Santoro não é plenamente dodecafônica e foi escrita em período inicial do movimento Música Viva em que obras de Villa-Lobos e de compositores nacionalistas como o próprio Camargo Guarnieri também eram executadas durante os concertos organizados por Koellreutter e seus alunos. Villa-Lobos também foi tema do sétimo e oitavo boletins do movimento Música Viva, além de ser responsável por introduzir o jovem Koellreutter ao cenário musical carioca da época. Irene Tourinho relata as memórias de Koellreutter:

Foi coisa romântica daquele tempo: criticávamos a vida cultural... não só a música, mas principalmente..." Lembra dos planos que deram certo e de como divulgavam suas idéias: "tinha o folheto do Grupo. Saíram 12 ou 13, de dois em dois meses e nós pagávamos tudo. O presidente de honra era o Villa-Lobos e participava também o Egídio de Castro e Silva e vários músicos da Orquestra Sinfônica: o Claudio Santoro, Guerra Peixe, Edino Krieger, Santino Parpinelli, Heitor Alimonda... Éramos todos músicos práticos - mudamos a orientação para dar ênfase à música de nosso tempo. Todos tornaram-se compositores”. (TOURINHO, 1999, p. 220).

A intenção inicial de Koellreutter com o movimento Música Viva era a divulgação, independente da estética, da música erudita contemporânea brasileira. Nesse sentido, era muito comum a presença de compositores como Francisco Mignone, Camargo Guarnieri e Villa-Lobos nos programas de concertos do Música Viva, pois esses eram os compositores mais produtivos no Brasil naquele momento. A renovação da linguagem a partir de técnicas que Koellreutter e seus alunos consideravam vanguardistas e a ruptura com o movimento nacionalista deu-se apenas em 1944, ano em que Koellreutter iniciou a transmissão do programa radiofônico semanal Música Viva, na rádio do Ministério da Educação.

O exemplo a seguir, extraído da análise de Joel Albuquerque para os c. 5-8 do Choros $n^{\circ} 7$, tem como objetivo identificar um possível encontro entre a linguagem de Villa-Lobos e o terceiro movimento da Primeira Sinfonia de Santoro (Fig. 7). 


\section{FIGURA 7}

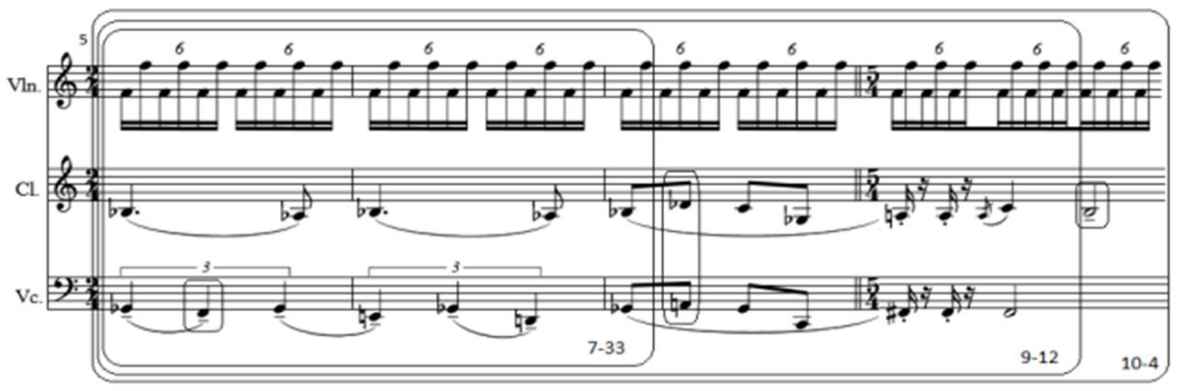

Villa-Lobos: Choros n 7, c. 5-8. Fonte: ALBUQUERQUE, 2014.

A análise de Joel Albuquerque (Fig. 7), apresenta um exemplo de como Villa-Lobos trabalhou com coleções simétricas em sua obra. Nos c. 5-6 há uma estrutura gerada a partir da coleção de tons inteiros (modo 1 de transposição limitada) com acréscimo da nota Fá (presente no ostinato executado pelo violino, e na linha do violoncelo). O acréscimo dessa nota estranha à coleção de tons inteiros gera o septacorde 7-33 (012468T). Logo em seguida (c. 7), temos a inclusão das alturas de Réb e Lá, resultando na coleção eneatônica 9-12 (01245689T) (modo 3 de transposição limitada). Finalmente (c. 8), temos o acréscimo da nota $\mathrm{Si}$, que encerra esse trecho gerando a coleção 10-4 (012345689T), também simétrica. ${ }^{1}$

Algo importante nessa passagem (Fig. 7) é a ideia de centralidade que acontece entre o eixo possibilitado pelo trítono Fá-Si. A nota Fá é mantida durante toda a estrutura, sendo inicialmente apresentada como nota "estranha" em escala paradigmática, deixando, logo em seguida, de ser incomum a estrutura escalar com a "modulação" para o modo 3. Ao final da estrutura temos a nota Si em situação de destaque temporal confirmando, com isso, a centralidade em Fá ou no eixo Fá-Si. Ou seja, a soma dos modos 1 e 3 resulta na coleção 10-4 em transposição que pode ser representada pela forma normal $[8,9,10,11,0,1,2,4,5,6]$. Com isso, enquanto nos modos de Messiaen é possível obter vários eixos de simetria em uma mesma transposição, na coleção 10-4 temos apena uma possibilidade de eixo que divide essa escala em partes iguais. Na transposição utilizada por Villa-Lobos é exatamente o eixo Fá-Si que foi destacado como centro da estrutura.

\footnotetext{
${ }^{1}$ Nota do editor: cabe lembrar que qualquer coleção com 10 classes de altura (assim como seu complemento, as díades) sempre apresenta simetria intervalar.
} 
A utilização de escalas paradigmáticas e modos de transposição limitada na obra de Villa-Lobos é comum. Como também o engendramento de texturas e estruturas a partir de sobreposições ou "modulações" entre diferentes escalas paradigmáticas, tendo como resultantes supercoleções que também são simétricas. No entanto, esses superconjuntos apresentam apenas uma possibilidade de eixo de simetria que é aproveitado pelo autor para definir centralidades, exatamente como acontece no exemplo apresentado na figura 7, em que o compositor vai acrescentando alturas "estranhas" à estrutura inicial, gerando modulações para diferentes coleções paradigmáticas que quando somadas geram uma supercoleção com um eixo de simetria que é destacado na estrutura.

Na mesma obra de Villa-Lobos podemos encontrar outras maneiras de concatenar essas coleções (Fig. 8).

\section{FIGURA 8}

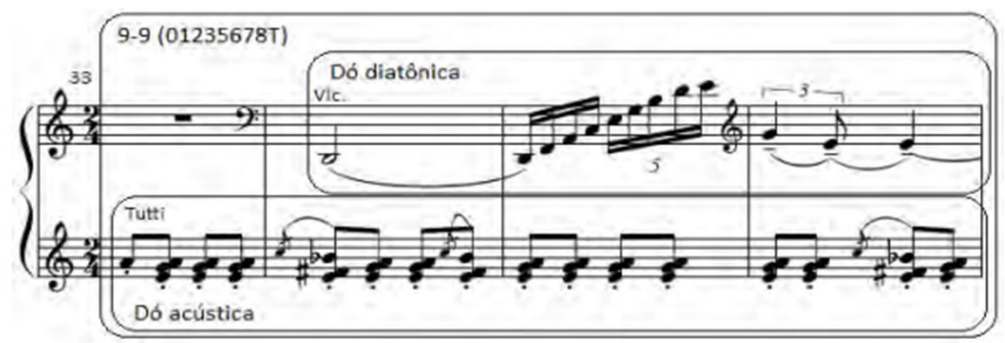

Villa-Lobos: análise do Choros n 7, c. 33-36. Fonte: ALBUQUERQUE, 2014.

$\mathrm{Na}$ figura 8 podemos perceber uma segunda maneira como Villa-Lobos trabalhou duas coleções paradigmáticas em uma mesma estrutura sonora no Choros $n^{\circ} 7$. Dessa vez, há uma melodia a cargo do violoncelo, desenvolvida a partir de escala diatônica de Dó (coleção diatônica 7-35) (013568T). Essa linha melódica é acompanhada pelos demais instrumentos, em harmonias alternadas entre dois acordes, que podem ser representados pelos conjuntos 3-7 (025) e 4-25 (0268); somados, geram o hexacorde 6Z23 (023568). 6-Z23 é um subconjunto da coleção octatônica, mas também pode ser compreendido como uma versão incompleta da escala acústica. No exemplo (Fig. 8) esta é a interpretação mais plausível, pois a nota Ré que falta no acompanhamento harmônico, está presente a partir do c. 34 na linha melódica efetuada pelo violoncelo. Ao sobrepor essas duas escalas temos como resultante a coleção 9-9 (01235678T) que é igualmente 
simétrica, com eixo em trítono gerado pelas alturas de Ré e Sol\#. Albuquerque ainda percebe uma possível centralidade em Ré:

O eixo Ré-Láb é mantido pela interação entre duas coleções de gêneros diferentes que surgem entre os compassos 33 e 36 , onde notamos a sobreposição das coleções Dó diatônica e Dó acústica, separadas em camadas distintas, formando agora um conjunto 9-9. Este complexo de nove classes de alturas é simétrico por reflexão em torno do eixo Ré-Láb e corrobora a centricidade aparente Ré, destacada na melodia do violoncelo no compasso 34 e reiterada entre os compassos 40 e 50 na melodia de oboé. Interessante notar que ambas as coleções Dó diatônica e Dó acústica mantêm em comum o mesmo eixo de reflexão invariante Ré-Láb. (ALBUQUERQUE, 2014, p. 220).

Santoro utilizou no terceiro movimento de sua Primeira Sinfonia algumas coleções semelhantes às que Villa-Lobos utilizou nos exemplos apresentados (Fig. 7 e 8). A coleção de dez elementos 10-4 e as coleções eneatônicas 9-12 e 9-9 são exemplos de escalas simétricas utilizadas por ambos os compositores. Abaixo temos um exemplo de ocorrência da coleção 9-9 na obra de Santoro (Fig. 9).

\section{FIGURA 9}

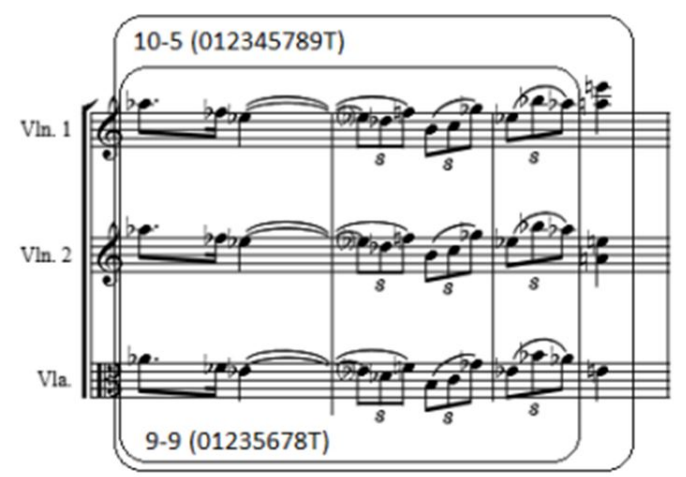

Análise de Santoro, Primeira Sinfonia, III, c. 35-37. Fonte: produção própria.

$\mathrm{Na}$ Figura 9 temos um excerto em que Santoro dobra um pequeno tema entre os violinos e a viola da primeira orquestra, trabalhando sobre a mesma estrutura rítmica utilizada nos compassos 28, 29 e 30 no violoncelo e primeiros e segundos violinos da segunda orquestra. Observe-se que naquele exemplo a sonoridade desenvolvida pelo tema foi o Modo 7 de transposição limitada, enquanto no caso exposto na Figura 9 a estruturação sonora usa a escala eneatônica 9-9 (012345789T). A díade Lá e Mi resulta em uma coleção de dez elementos, o conjunto 10-5 (012345789T), com eixo de simetria no quarto de tom entre Mi-Fá e Sib-Si, levando em consideração a transposição do exemplo em questão que pode ser representado pela forma normal $[8,9,10,11,0,1,3,4,5,6]$. 
Tal estrutura de dez sons também aparece no Choros $n^{\circ} 4$ de Villa-Lobos, como demonstra Joel Albuquerque (Fig. 10).

\section{FIGURA 10}

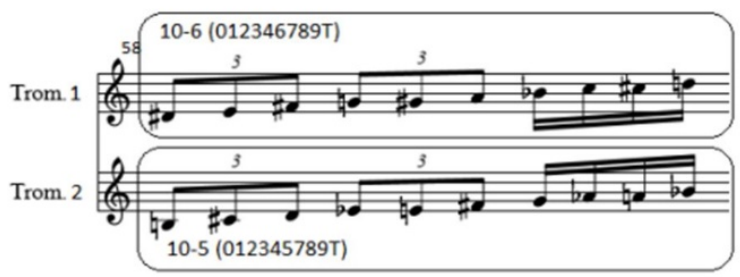

Análise de Villa-Lobos, Choros $n^{\circ}$ 4, c. 58. Fonte: ALBUQUERQUE (2014).

A figura 10 nos apresenta o c. 58 do Choros $n^{\circ} 4$ de Villa-Lobos em que a I e II trompas executam um tema com o mesmo material rítmico, mas em formatações escalares distintas. A primeira trompa é construída a partir do conjunto 10-6 o modo 7 de transposição limitada e na segunda trompa temos a coleção 10-5 que também é simétrica, contudo, não possui limitação de transposição, tal como acontece com o modo 7. Apesar da distinção entre essas coleções de dez elementos Villa-Lobos as gerou a partir de procedimento semelhante, que foi a intercalação entre diferentes transposições do pentacorde 5-35 (02479). Na primeira trompa temos intercalação entre as formas normais $[6,8,10,1,3]$ e $[0,2,4,7,9]$, ou seja, a primeira pentatônica está no sexto nível de transposição e a segunda em nível que se confunde com sua forma prima, isso é, formatação escalar a partir de Dó. Na segunda trompa veremos alternância entre as formas normais $[7,9,11,2,4]$ e $[6,8,10,1,3]$, temos, portanto, uma pentatônica no sétimo nível de transposição e uma no sexto nível de transposição.

Nessa perspectiva podemos concluir que o autor simplesmente alternou as notas "brancas" com as "pretas" do piano, conseguindo efetuar diferenciação entre as coleções de dez elementos com a intercalação entre pentacordes relacionados por níveis distintos de transposição. Na primeira trompa os pentacordes estão relacionados por um trítono de diferença entre os conjuntos intercalados gerando o modo 7 de Messiaen, na segunda trompa observamos apenas meio tom de diferença possibilitando o engendramento da coleção 10-5. Algo interessante de ser percebido é que a única distinção entre essas coleções com dez elementos foi a alteração de uma altura nas pentatônicas relacionadas com as teclas "brancas" do piano. Na primeira trompa a ocorrência da nota Dó, na 
segunda trompa temos a nota Si. Isso é o suficiente para gerar duas escalas simétricas que são divergentes em algumas características, dentre elas, as possibilidades de transposições, isso é, enquanto uma é limitada, contendo apenas seis possibilidades de transposição, a outra pode ser transposta para todos os níveis.

Como podemos constatar, Claudio Santoro utilizou no terceiro movimento de sua Primeira Sinfonia várias sonoridades que são frequentes na obra de Villa-Lobos, dentre elas, podemos citar os modos 2 (escala octatônica), 3 (escala eneatônica) e 7 de transposição limitada, o nonacorde 9-9 e as supercoleções 10-4 e 10-5. No entanto, os procedimentos de utilização dessas escalas são divergentes em determinados aspectos. Em Santoro, observamos a utilização dessas coleções a partir de sobreposições entre diferentes camadas, nas quais algumas dessas estruturas sonoras são expostas em pequenos temas recorrentes e destacadas por dobramentos orquestrais, possibilitando o engendramento de texturas polifônicas densas, efetuando, com isso, constantes saturações cromáticas. Já na obra de Villa-Lobos apesar de identificarmos o empilhamento dessas coleções em diferentes camadas, há uma constante preocupação de definir centros que são derivados a partir de supercoleções que possuem eixo de simetria fixo.

Devemos sempre ter em mente que estamos comparando uma peça de juventude de Santoro em relação a obras muito bem resolvidas, escritas em período muito fértil de Villa-Lobos. Nesse sentido, é evidente que haja muito mais domínio dos materiais empregados nas obras exemplificadas de Villa-Lobos em relação a obra escrita por Santoro. Todavia, seja impressionante a capacidade criadora e consciência compositiva que Santoro já demonstra com tão pouca idade. Outra característica interessante de ser percebida nessa obra inaugural de Santoro é a sintonia com procedimentos composicionais aplicados por seus contemporâneos, procurando construir sua linguagem a partir de alinhamento entre suas particularidades e a técnica vanguardista de seu tempo, característica que também é percebida na obra de Villa-Lobos.

\section{Conclusão}

A análise da estrutura pós-tonal da Primeira Sinfonia para duas orquestras de cordas de Claudio Santoro é relevante para o entendimento da gênese da linguagem póstonal do compositor, bem como para o reconhecimento de uma provável influencia para 
Koellreutter e seus demais colegas do Movimento Música Viva, uma vez que esta obra impulsionou o desejo do estudo das teorias dodecafônicas pelo grupo de jovens compositores que se agruparam em torno em torno de Koellreutter e Santoro.

Nessa obra podemos evidenciar diferentes procedimentos da música pós-tonal. A partir da identificação desses procedimentos no primeiro e terceiro movimentos também foi possível apontar algumas influências, além de identificar alguns autores que realizaram processos composicionais semelhantes aos encontrados nessa sinfonia.

O primeiro movimento "Allegro majestoso" da Primeira Sinfonia de Santoro foi construído a partir de determinadas configurações temáticas que sofrem pequenas transformações estruturais como a ampliação e diminuição dos valores das figuras rítmicas. A manipulação temática efetuada nessa peça acontece através de variadas reordenações dessas configurações temáticas e suas inserções em diferentes timbres. Essas microestruturas também são utilizadas para gerar momentos com polifonia densa, possibilitadas a partir de sobreposições de diferentes transposições de coleções importantes para a configuração sonora da peça. Este procedimento pode ser comparado a um mosaico construído com poucas peças que são desconfiguradas e reconfiguradas.

Nesse mesmo movimento também podemos identificar a utilização de algumas sonoridades paradigmáticas para a música pós-tonal da primeira metade do século vinte. Dentre essas sonoridades a pentatônica 5-35 (02479) é a que mais ocorre na estrutura da peça em questão, aparecendo em diferentes transposições e configurações, privilegiando as sonoridades quartais que lhe são idiomáticas.

A coleção de tons-inteiros 6-35 (02468T) também é importante para a efetuação da característica sonora do primeiro movimento da Primeira Sinfonia, assim como ocorre com a coleção pentatônica 5-35, a escala de tons-inteiros foi muito utilizada no contexto harmônico, ocorrendo através de sobreposições entre diferentes transposições da tríade aumentado 3-12 (048), tal união acaba resultando em determinadas transposições da escala de tons-inteiros. Outra característica importante de ser apontada é as variadas formatações harmônicas que Santoro criou a partir de relações impostas sobre a escala pentatônica 5-35 e a coleção de tons-inteiros 6-35 em algumas configurações essas coleções aparecem em blocos de acordes sobrepostos, em outros momentos a relação 
entre essas acordes acontecem a partir de concatenação horizontal dessas estruturas harmônicas.

Outra estrutura harmônica importante no primeiro movimento da Primeira Sinfonia foi a coleção acústica 7-34 (013468T) que produziu algumas pontuações harmônicas, além das relações parcimoniosas que esta coleção tem com outras escalas como a coleção de tons-inteiros e a diatônica, além de ter contida em sua estrutura a coleção pentatônica 5-35. Estas coleções e a maneira como elas foram utilizadas na peça em questão pode evidenciar a influência que Cláudia Santoro tinha da música de autores franceses como Claude Debussy e Maurice Ravel. As configurações harmônicas quartais acabam evidenciando uma sonoridade contida na obra de Paul Hindemith que Santoro conheceu no estudo com Koellreutter.

O terceiro movimento "Allegro Final e Fugato", mostrou-se como sendo o mais complexo dentre os três movimentos da Primeira Sinfonia de Santoro. Nessa peça, Santoro trabalhou com entidades sonoras simétricas em amplo nível. Utilizou escalas de natureza extremamente simétricas como foi o caso da escala octatônica paradigmática 828 (0134679T), a coleção eneatônica 9-12 (01245689T), a coleção octatônica 8-9 (01236789) e a coleção decafônica 10-6 (012346789T), sendo todas essas coleções modos de transposição limitada. Tais sonoridades engendram estruturas sonoras densas que a partir da sobreposição de determinadas configurações, tornou possível obter outras coleções também simétricas. Nesse sentido, Santoro parte de sonoridade com elevado nível de simetria que quando somadas produzem macroestruturas que são simétricas em apenas um eixo, possibilitando o aproveitamento da ideia de centralidade a partir de eixo de simetrias.

Essas caraterísticas estruturais presentes no terceiro movimento da Primeira Sinfonia de Santoro apontam semelhanças com alguns procedimentos desenvolvidos por Heitor Villa-Lobos em obras como o Choros $n^{\circ} 7$ e Rudepoema nas quais é possível identificar a utilização de escalas simétrica que quando agrupadas em variadas texturas, acabam produzindo novas estruturas simétricas em que é possível destaca uma centralidade a partir de eixo de simetria único. 


\section{Referências}

ANDRADE, Mário de. Ensaio Sobre a Música Brasileira. 3. ed. São Paulo: Livraria Martins, 1972.

ANTUNES, Jorge. O ofício do compositor. In: TRAGTENBERG, Livio (org.). O Oficio do Compositor Hoje. São Paulo: Perspectiva, p. 103-139, 2012.

ALBUQUERQUE, Joel M. B. de. Simetria Intervalar e Rede de Coleções: Análise Estrutural dos Choros $n^{\circ} 4$ e Choros $n^{\circ} 7$ de Heitor Villa-Lobos. São Paulo: Universidade de São Paulo, 2014.

BARROS, Frederico. César Guerra Peixe e Heitor Villa-Lobos: Vanguarda, Nacionalismo e Nacionalismo de Vanguarda. XIV Encontro regional da ANPUH-Rio, 2010.

BRITO, Teca de Alencar. Hans-Joachim Koellreutter: ideias de mundo, de música, de educação. São Paulo: EDUSP, 2015.

COELHO DE SOUZA, Rodolfo. A recepção das teorias do dodecafonismo nos últimos Quartetos de cordas de Claudio Santoro. Revista Brasileira de Música, v. 24, p. 329-350, 2012.

EGG, André. A Carta Aberta de Camargo Guarnieri. Revista Científica/FAP, Curitiba, v. 1, 2006.

O Grupo Música Viva e o Nacionalismo Musical. Escola de Música e Belas Artes do Paraná, III Fórum de Pesquisa Cientifica em Arte, 2005.

FORTE, Allen. The Structure of Atonal Music. New Haven and London: Yale University Press, 1973.

KOSTKA, Stefan. Materials and Techniques of Twentieth-Century Music. Englewwod Cliffs: Prentice Hall, 1990.

KATER, Carlos. Música Viva e H. J. Koellreutter: movimentos em direção à modernidade. São Paulo: Musa Editora, 2001.

LÍVERO DE SOUZA, Iracele Vera. Reflexões, experiências e opiniões do compositor Claudio Santoro. Opus, v. 11, p. 304-319, 2005.

MARIZ, Vasco. Claudio Santoro, vida e obra. Rio de Janeiro: Nova Fronteira, 1990.

MARQUES DE OLIVEIRA, Reinaldo. Claudio Santoro e o Dodecafonismo: um procedimento singular. Dissertação (Mestrado em Música). 157 p. São Paulo: Universidade de São Paulo, 2005.

MENDES, Sérgio Nogueira. O Percurso Estilístico de Claudio Santoro: Roteiro Divergente e Conjunção Final. Tese de Doutorado em Música. Orientador: Silvio Ferraz de Mello Filho. Campinas: Universidade Estadual de Campinas, 2009. Disponível em: http://repositorio.unicamp.br/jspui/handle/REPOSIP/284014, acesso em 20 dez. 2019.

MESSIAEN, Oliver. Technique de mon langage musical. Paris: Alphonse Leduc, 1966.

NEVES, José Maria. Música Contemporânea Brasileira. 2. ed. Rio de Janeiro: Contra Capa Livraria. 2008. 
OLIVEIRA, Jamary. Black Key versus White Key: A Villa-Lobos Device. Latin American Music Review, v. 5, n. 1, p. 33-47, 1984.

PAZ, Juan Carlos. Introdução à música de nosso tempo. São Paulo: Livraria Duas Cidades. 1976.

ROIG-FRANCOLÍ, Miguel. Understanding Post-Tonal Music. New York: McGraw-Hill, 2008.

SALLES, Paulo de Tarso. Villa-Lobos: Processos Composicionais. Campinas: Unicamp, 2009.

SANTORO, Alessandro. Um Estudo Analítico da Sonata para flauta (1941) de Claudio Santoro. Musica Theorica, v. 2, n. 2. 2017.

SOUZA, Leandro Candido de. H. J. Koellreutter e a Revista Música Viva: apontamentos sobre a modernidade musical brasileira. Faces da História. Assis-SP, v. 1, n. 2, p. 161-185, 2014.

STRAUS, Joseph N. Introdução à teoria pós-tonal. New Jersey: Prentice Hall. 1990.

TOURINHO, Irene. Encontros com Koellreutter: sobre suas histórias e seus mundos. Estudos Avançados, v. 13, n. 36, p. 209-223, 1999.

TYMOCZKO, Dmitri. A Geometry of Music: Harmony and Counterpoint in the Extended Common Practice. New York: Oxford University Press, 2011.

. Scale Networks and Debussy. Journal of Music Theory, v. 51, n. 2, p. 219-294, 2004. 